\title{
Instability in the faecal flora of a patient suffering from food-related irritable bowel syndrome
}

\author{
HAZEL K. BRADLEY, G. M. WYATTt, CATHERINE E. BAYLISS and J. O. HUNTER* \\ Agricultural and Food Research Council, Institute of Food Research, Norwich Laboratory, Colney Lane, Norwich \\ NR4 7UA and *Department of Gastroenterology, Addenbrookes Hospital, Hills Road, Cambridge CB2 200
}

Summary. The faecal microbial flora of a patient with severe irritable bowel syndrome related to multiple food intolerances was very variable and contained a high proportion of facultative bacteria and an unusual incidence of Clostridium species.

\section{Introduction}

It is recognised that intolerance to specific foods or food components is important in some patients suffering from irritable bowel syndrome (IBS) and diet management has been successful in controlling symptoms (Hunter and Alun-Jones, 1985; Hunter et al., 1985). Several factors suggest involvement of the intestinal flora and patients may have variable faecal floras, with higher total counts of facultative bacteria (Bayliss et al., 1984) or higher proportions of gram-negative facultative bacteria (Bradley et al., 1985) than controls.

Some patients exhibit extreme symptoms with multiple intolerances and are restricted to very limited diets. It has been recommended that these patients return to management by drug treatment rather than attempt complex exclusion diets (Hunter et al., 1985). In view of the established value of antibiotic treatment in diverticulitis (Larson et al., 1976) and pseudomembranous colitis (Tedesco et al., 1978), together with the possible involvement of the intestinal flora and previous work on gut sterilisation and sterile diets in IBS (Kane and Neale, 1976), courses of antibiotics were prescribed. The patient in this study had not responded to pharmacological management. Her multiple food intolerances resulted in a severely restricted diet and, at times, total parenteral nutrition was required to sustain her. To assess whether the composition of the intestinal flora was abnormal, microbial analyses were performed on samples of faeces collected during a period of 18 months.

Received 11 Nov. 1985; accepted 13 Jan. 1986.

† Correspondence should be sent to G. M. Wyatt.

\section{Patients and methods}

\section{Case history of patient $P 2$}

A 42-year old woman presented 6 weeks after hysterectomy, with abdominal pain, diarrhoea, severe headaches and muscular weakness. These symptoms have been shown to be associated with food intolerance developing after hysterectomy (Alun-Jones et al., 1984). The initial response of patient $\mathbf{P} 2$ to an elimination diet was good, but many foods provoked symptoms when re-introduced. Subsequently, on a limited diet, her weight was maintained between 45 and $50 \mathrm{~kg}$ by dietary supplementation with proprietary medium-chain-triglyceride feeds (Trisorban). Indices of nutrition including serum albumin, pre-albumin and transferrin have been maintained at normal levels.

Courses of antibiotics and total parenteral nutrition (TPN) with no oral intake other than sterile water were employed in an attempt to allow her to eat a wider variety of foods. TPN was used on three occasions in 1981, 1982 and 1983 for periods of 4-12 weeks. On the first occasion, immediately after TPN, she was able to eat a wider range of foods for several months, but the number of food intolerances eventually rose again. On subsequent occasions the improvement was of much shorter duration.

\section{Faecal bacterial counts}

Freshly voided stools were collected in a plastic bag and immediately placed in an anaerobic cabinet (Forma Scientific) containing an atmosphere of $\mathrm{N}_{2} 85 \%, \mathrm{H}_{2} 10 \%$ and $\mathrm{CO}_{2} 5 \%$. After kneading by hand, $1 \mathrm{~g}$ was transferred to a pre-weighed bottle containing glass beads and $10 \mathrm{ml}$ of anaerobic dilution solution (ADS; Bryant and Burkey, 1953). After reweighing, the contents were mixed to form a slurry by vortex mixing. A tenfold dilution series was prepared in ADS and $0 \cdot 1-\mathrm{ml}$ volumes were plated on pre-reduced VLhlf agar, a complex medium on which a high proportion of faecal anaerobic bacteria can be isolated (Croucher et al., 1983), and incubated in the cabinet for 7 days at $37^{\circ} \mathrm{C}$ for determination of the viable 
anaerobic count. Outside the cabinet, $0.03-\mathrm{ml}$ volumes were plated on CLED Agar (Oxoid) and incubated aerobically for 2 days at $37^{\circ} \mathrm{C}$ to determine the viable count of facultative bacteria.

A sample of the faeces was dried to constant weight at $100^{\circ} \mathrm{C}$ for determination of moisture content.

Similar counts were performed on single faecal samples from two daughters of the patient (P2A and P2B) who showed no symptoms of IBS.

\section{Isolation and characterisation of organisms}

Twenty colonies from the highest dilution showing growth on VLhlf plates were purified by streaking on to VLhlf agar. Single colonies were selected after incubation for up to 5 days at $37^{\circ} \mathrm{C}$, inoculated into tubes of SM10 agar (Barnes and Impey, 1974), a complex medium suitable for use in oxygen-free $\mathrm{CO}_{2}$ (Hungate, 1969). All subsequent manipulations were performed by this method unless otherwise stated. After checking isolates for aerobic growth, obligate anaerobes were identified to genus level by the methods of Holdeman et al. (1977). Preliminary identification of aerobic isolates was made on CLED agar and further characterisation of organisms isolated from the highest dilutions was by the API $20 \mathrm{E}$ system (API Laboratory Products, Basingstoke, Hants) or by the methods of Cowan (1974). Isolates were maintained by freezing at $-70^{\circ} \mathrm{C}$.

\section{Results}

\section{Faecal bacterial counts}

The total viable bacterial counts in faeces from patient P2 during an 18-month period varied between $1.3 \times 10^{10}$ and $5.9 \times 10^{11} / \mathrm{g}$ (dry weight) of faeces (table I). The proportions of facultative organisms in these counts were from $72 \%(\mathrm{P} 2 / 7)$ to $0.7 \%(\mathrm{P} 2 / 5)$. The moisture content of faeces varied by more than $25 \%$.

Similar total counts were found in specimens from P2A and P2B but the proportions of facultative bacteria were $\ll 0.01 \%$ of the total counts.

\section{Bacteria isolated}

The rank order of species in samples from P2 varied considerably from count to count (table II); in several samples species of Clostridium formed a considerable proportion of the obligate anaerobes and in one sample (P2/2) all obligate anaerobes isolated were Clostridium spp. The dominant facultative organisms in P2 samples were Streptococcus spp, Escherichia coli and Proteus spp.

In samples from $\mathrm{P} 2 \mathrm{~A}$ and $\mathrm{P} 2 \mathrm{~B}$, the principal obligate anaerobes were Bacteroides and Bifidobacterium spp, with $E$. coli dominating the facultative flora.

\section{Discussion}

The faecal flora of the patient in this study contained a high proportion of facultative organisms, in contrast to the findings of Moore and Holdeman (1974) that the dominant facultative species, E. coli and Str. salivarius, were each present at a mean of $0.4 \%$ of the total count. As in the study of Finegold et al. (1974), E. coli, Str. faecalis and Str. faecium were the dominant facultative bacteria. Moore and Holdeman (1974), Holdeman et al. (1976) and Moore et al. (1981) found that the most

Table I. Viable counts and moisture contents of faecal samples from patient $\mathrm{P} 2$ and daughters $\mathrm{P} 2 \mathrm{~A}$ and $\mathrm{P} 2 \mathrm{~B}$.

\begin{tabular}{|c|c|c|c|c|c|}
\hline \multirow[b]{2}{*}{ Count no. } & \multirow[b]{2}{*}{ Date } & \multicolumn{2}{|c|}{$\begin{array}{c}\text { Viable count } \\
\log _{10} / g \text { (dry weight) }\end{array}$} & \multirow{2}{*}{$\begin{array}{l}\text { Ratio of counts, } \\
\text { total: facultative }\end{array}$} & \multirow{2}{*}{$\begin{array}{r}\text { Moisture } \\
\text { content( } \%\end{array}$} \\
\hline & & total & facultative & & \\
\hline $\mathrm{P} 2 / 0$ & 18 Jun. 83 & ND & $11 \cdot 15$ & - & $77 \cdot 3$ \\
\hline $\mathrm{P} 2 / 1$ & 22 Jul. 83 & $10 \cdot 11$ & $9 \cdot 72$ & $2 \cdot 6: 1$ & $58 \cdot 1$ \\
\hline $\mathrm{P} 2 / 2$ & 4 Aug. 83 & 10.53 & $9 \cdot 56$ & $9 \cdot 4: 1$ & $84 \cdot 2$ \\
\hline $\mathrm{P} 2 / 3$ & 8 Aug. 83 & $10 \cdot 75$ & $10 \cdot 15$ & $4 \cdot 0: 1$ & $86 \cdot 6$ \\
\hline $\mathrm{P} 2 / 4$ & 6 Sep. 83 & $11 \cdot 77$ & $10 \cdot 89$ & $7 \cdot 6: 1$ & $62 \cdot 5$ \\
\hline $\mathrm{P} 2 / 5$ & 7 Nov. 83 & $10 \cdot 23$ & 8.08 & $138: 1$ & $66 \cdot 1$ \\
\hline $\mathrm{P} 2 / 6$ & 17 Jan. 84 & $11 \cdot 26$ & 9.49 & $57: 1$ & $81 \cdot 8$ \\
\hline $\mathrm{P} 2 / 7$ & 5 Jan. 85 & $10 \cdot 48$ & $10 \cdot 34$ & $1.4: 1$ & $71 \cdot 4$ \\
\hline $\mathrm{P} 2 \mathrm{~A} / 1$ & 5 Jan. 85 & $11 \cdot 40$ & $6 \cdot 38$ & $104,000: 1$ & $62 \cdot 4$ \\
\hline $\mathrm{P} 2 \mathrm{~B} / 1$ & 5 Jan. 85 & $11 \cdot 86$ & $7 \cdot 26$ & $41,000: 1$ & $60 \cdot 0$ \\
\hline
\end{tabular}

$\mathrm{ND}=$ not done. 
Table II. Principal organisms ( $\geqslant 10 \%$ of isolates) in faecal samples from P2 and her daughters

\begin{tabular}{|c|c|c|c|c|c|}
\hline \multirow[b]{2}{*}{ Count no. } & \multirow[b]{2}{*}{ Date } & \multicolumn{2}{|c|}{ Anaerobes } & \multicolumn{2}{|c|}{ Facultative bacteria } \\
\hline & & Genus & $\begin{array}{l}\text { Percentage of } \\
\text { total isolates }\end{array}$ & Genus (or species) & $\begin{array}{l}\text { Percentage of } \\
\text { total isolates }\end{array}$ \\
\hline \multirow[t]{2}{*}{$\mathrm{P} 2 / 0$} & 18 Jun. 83 & Not tested & - & Streptococcus & 45 \\
\hline & & & & Proteus & 40 \\
\hline \multirow[t]{2}{*}{$\mathrm{P} 2 / 1$} & 22 Jul. 83 & Bacteroides & 50 & Str. faecalis & 60 \\
\hline & & Clostridium & 30 & E. coli & 30 \\
\hline $\mathbf{P} 2 / 2$ & 4 Aug. 83 & Clostridium & 100 & Str, faecalis & 99 \\
\hline \multirow[t]{3}{*}{$\mathrm{P} 2 / 3$} & 8 Aug. 83 & Clostridium & 60 & Streptococcus & 40 \\
\hline & & Lactobacillus & 30 & P. mirabilis & 35 \\
\hline & & Bifidobacterium & 10 & E. coli & 25 \\
\hline \multirow[t]{5}{*}{$\mathrm{P} 2 / 4$} & 6 Sep. 83 & Bacteroides & 30 & E. coli & 90 \\
\hline & & Clostridium & 20 & Str. faecium & 10 \\
\hline & & Ruminococcus & 10 & & \\
\hline & & Lactobacillus & 10 & & \\
\hline & & Bifidobacterium & 10 & & \\
\hline \multirow[t]{3}{*}{$\mathrm{P} 2 / 5$} & 7 Nov. 83 & Lactobacillus & 26 & E. coli & 55 \\
\hline & & Bacteroides & 25 & Streptococcus & 32 \\
\hline & & Clostridium & 22 & P. mirabilis & 12 \\
\hline \multirow[t]{3}{*}{$\mathrm{P} 2 / 6$} & 17 Jan. 84 & Ruminococcus & 40 & Proteus & 50 \\
\hline & & Bacteroides & 25 & E. coli & 25 \\
\hline & & Clostridium & 10 & Streptococcus & 25 \\
\hline $\mathrm{P} 2 / 7$ & 5 Jan. 85 & $\begin{array}{l}\text { Predominantly } \\
\text { facultative }\end{array}$ & & Str. faecium & 85 \\
\hline \multirow[t]{3}{*}{$\mathrm{P} 2 \mathrm{~A} / 1$} & 5 Jan. 85 & Bacteroides & 50 & E. coli & 99 \\
\hline & & Bifidobacterium & 30 & & \\
\hline & & Eubacterium & 10 & & \\
\hline \multirow[t]{2}{*}{$\mathrm{P} 2 \mathrm{~B} / 1$} & 5 Jan. 85 & Bifidobacterium & 85 & E. coli & 95 \\
\hline & & Bacteroides & 15 & & \\
\hline
\end{tabular}

abundant obligate anaerobes in faeces from normal individuals were Bacteroides, Bifidobacterium, Eubacterium, Peptostreptococcus, Fusobacterium and Ruminococcus spp. and the authors concluded that each individual tends to maintain a characteristic pattern of species, in marked contrast to the variation shown in this patient. Moore and Holdeman (1974) also found that in 20 healthy individuals, Clostridium spp. represented $<5 \%$ of the flora, again in contrast to $\mathrm{P} 2$.

In a study of the microbial populations of patients with IBS, but not specifically associated with food intolerance, Balsari et al. (1982) noted the appearance, in 6 out of 20 patients, of facultative species (Pseudomonas and enterobacteria) which were not present in control subjects. Furthermore, the numbers of E. coli and Bifidobacterium spp. were lower in patients, but the numbers of clostridia did not differ between patients and controls. The authors suggested that the differences were related to the peristaltic disturbances found in IBS patients but queried whether the flora was influenced by the repeated antibiotic therapy which these patients undergo. Before taking the sample for count $\mathbf{P} 2 / 1$ the patient was treated at intervals with oxytetracycline; a high level of resistance to this antibiotic was found amongst isolates from sample $\mathrm{P} 2 / 1$; this declined in subsequent counts (data not presented). Between counts $\mathrm{P} 2 / 1$ and $\mathrm{P} 2 / 2$ the patient was treated with colistin sulphate, nalidixic acid, trimethoprim and vancomycin, and strains of two genera present in count $\mathrm{P} 2 / 1$ (Bacteroides and $E$. coli) were not detected in $\mathrm{P} 2 / 2$. It seems likely that antibiotic therapy could account for the temporary disappearance of $E$. coli (which reappeared in count $\mathrm{P} 2 / 3$ ) but it is more difficult to attribute the simultaneous loss of Bacteroides directly to the antibiotic treatment used.

In a healthy individual, the composition of the gut flora is affected by complex regulatory forces (Savage, 1982) exerted partly by the host's physiological and immunological status and partly by the microbial community itself. Although the rank order of species in the flora is usually stable, the characteristics of the population may change with diet (Wyatt et al., 1986). It has been established that 
the symptoms of food-related IBS connect specific foodstuffs and specific individuals (Hunter and Alun-Jones, 1985); the variable faecal flora seen in patient P2 and in some other patients (Bayliss et al., 1984; Bradley et al., 1985) may be a further factor,

\section{REFERENCES}

Alun-Jones V, Wilson A J, Hunter J O, Robinson R E 1984 The aetiological role of antibiotic prophylaxis with hysterectomy in irritable bowel syndrome. Journal of Obstetrics and Gynaecology 5 Suppl 1:S22-S23.

Balsari A, Ceccarelli A, Dubini F, Fesce E, Poli G 1982 The fecal microbial population in the irritable bowel syndrome. Microbiologica 5:185-194.

Barnes E M, Impey C S 1974 The occurrence and properties of uric acid decomposing anaerobic bacteria in the avian caecum. Journal of Applied Bacteriology 37:393-409.

Bayliss C E, Houston A P, Alun-Jones V, Hishon S, Hunter J O 1984 Microbiological studies on food intolerance. Proceedings of the Nutrition Society 43:16A.

Bradley H K, Bayliss C E, Wyatt G M, Smyth A F, Alun-Jones V, Hunter J O 1985 Food intolerance and microbial populations in the human colon. In: Recent advances in anaerobic bacteriology, Martinus Nijhoff, Dordrecht.

Bryant M P, Burkey L A 1953 Cultural methods and some characteristics of some of the more numerous groups of bacteria in the bovine rumen. Journal of Dairy Science 36:205-217.

Cowan S T 1974 Cowan and Steel's Manual for the identification of medical bacteria, 2nd edn, Cambridge University Press, Cambridge.

Croucher S C, Houston A P, Bayliss C E, Turner R J 1983 Bacterial populations associated with different regions of the human colon wall. Applied and Environmental Microbiology 45: 1025-1033.

Finegold S M, Attebery H R, Sutter V L 1974 Effect of diet on human fecal flora: comparison of Japanese and American diets. American Journal of Clinical Nutrition 27:1456-1469.

Holdeman L V, Cato E P, Moore W E C 1977 Anaerobe Laboratory Manual, 4th ed. Virginia Polytechnic Institute, Blacksburg, pp. 69-82.

Holdeman L V, Good I J, Moore W E C 1976 Human fecal flora: but the underlying mechanisms involved are not yet known.

We thank Anne Smyth for skilled technical assistance with part of this work.

variation in bacterial composition within individuals and possible effect of emotional stress. Applied and Environmental Microbiology 31:359-375.

Hungate R E 1969 A roll tube method for cultivation of strict anaerobes. In: Norris J R, Ribbons D W (eds) Methods in microbiology, vol. 3B. Academic Press, London, pp 117 132.

Hunter J O, Alun-Jones V 1985 Studies on the pathogenesis of irritable bowel syndrome produced by food intolerance. In: Read NW (ed) Irritable bowel syndrome. Grune and Stratton Inc., pp 185-189.

Hunter J O, Workman E, Alun-Jones V 1985 Dietary Studies. In: Jewell D P, Gibson P R (eds) Topics in gastroenterology 12, Blackwell Scientific, Oxford, p 313.

Kane S P, Neale G 1976 Ileo-colitis responding to bowel sterilization. Proceedings of the Royal Society of Medicine, 69:266.

Larson D M, Masters S S, Spiro H M 1976 Medical and surgical therapy in diverticular disease-a comparative study. Gastroenterology, 71:734-737.

Moore W E C, Cato E P, Good I J, Holdeman L V, 1981 The effect of diet on the human faecal flora. In: Bruce W R et al. (eds) Banbury Report 7: Gastrointestinal cancer. Cold Spring Harbor Laboratory, New York, pp 11-19.

Moore W E C, Holdeman L V 1974 Human fecal flora: the normal flora of 20 Japanese-Hawaiians. Applied Microbiology 27:961-979.

Savage D C 1983 Effect of food and fibre on the intestinal luminal environment. In: Wallace G, Bell L (eds) Fibre in human and animal nutrition, Royal Society of New Zealand, Wellington, pp 125-129.

Tedesco F, Markham R, Gurwith M, Christie D, Bartlett J G 1978 Oral Vancomycin therapy for antibiotic-associated pseudomembranous colitis. Lancet 2:226-228.

Wyatt G M, Bayliss C E, Holcroft J D 1986 A change in human faecal flora in response to inclusion of gum arabic in the diet. British Journal of Nutrition, 55:261-266. 